\title{
DETERMINANT ANALYSIS OF ENTREPRENEURIAL INTENTION AMONG MILLENNIAL IN YOGYAKARTA, INDONESIA
}

\author{
Dr. Lilies Setiartiti \\ Lecturer \\ Department of Economics \\ Universitas Muhammadiyah Yogyakarta, Indonesia \\ E-mail: setiartiti.lilies1267@gmail.com \\ Nur Azizah Ramadanty Sadik \\ Department of Economics \\ Universitas Muhammadiyah Yogyakarta, Indonesia \\ E-mail: azizahsadik20@gmail.com
}

\begin{abstract}
ABSTARCT
This study aims to analyze the determinant of millennial entrepreneurial intention in Yogyakarta. The subject in this study was the people resident in Yogyakarta with the age of 19 to 39 years old. Respondents were selected using a purposive sampling method. The data were gathered using questionnaires and analyzed by using multiple linear regression analysis. The finding of this study shows that overall the attitude, perceived behavioral control, family background, entrepreneurial knowledge, and social media have a positive and significant impact on entrepreneurial intention simultaneously. Whereas separately the results show that attitude, behavioral control, family background, and social media have a positive and significant impact on entrepreneurial intention while entrepreneurial knowledge has a negative and insignificant of the millennial generation in Yogyakarta. Overall, this research provides some crucial insights for Yogyakarta's local government to highlight possible steps for policy makers as a reference for entrepreneurship development.
\end{abstract}

Keywords: Millennial, Entrepreneurial Intention, Yogyakarta.

\section{INTRODUCTION}

Indonesia is the fourth country with the most population in the world. Residents can certainly experience a change in transformation due to the development of the times. Based on the intercensus population survey, Indonesia's population in 2019 is projected to reach 266.91 million. According to gender, the number consisted of 134 million men and 132.89 million women. Indonesia is currently enjoying a demographic bonus period in which the number of productive age population is more than the unproductive age, which is more than $68 \%$ of the total population. A demography bonus is a situation where productive age is more than unproductive age. Productive age is the population of the age group of 15 to 64 years while the non-productive age is the population of the age group of 64 years and above. With the bonus demography, it will 
create a variety of new jobs but at the same time, the demographic bonus also harms the unemployment rate if the available jobs do not match the skills they have. Unfortunately, even with the demographic bonus situation, Indonesia still faces a high unemployment rate.

Yogyakarta is one of the provinces located on the island of Java. Based on the Bureau Regional Secretariat Administration Yogyakarta, the total population of Yogyakarta in 2018 is 3.631.015 people. Yogyakarta has the lowest unemployment rate compared to another province in Java. The open unemployment rate or commonly referred to as the unemployment rate describes the proportion of the workforce who are unemployed and looking for work, preparing for a business, desperate to find work, and who already have a job but have not started work. The following table is the open unemployment rate of Yogyakarta from 2015 to 2018:

Table 1.Open Unemployment Rate of Province in Java

\begin{tabular}{|l|c|c|c|c|}
\hline \multirow{2}{*}{ Province in Java } & \multicolumn{4}{|c|}{ Year } \\
\cline { 2 - 5 } & $\mathbf{2 0 1 5}$ & $\mathbf{2 0 1 6}$ & $\mathbf{2 0 1 7}$ & $\mathbf{2 0 1 8}$ \\
\hline Jakarta & 7,23 & 6,12 & 7,14 & 6,24 \\
\hline West Java & 8,72 & 8,89 & 8,22 & 8,17 \\
\hline Central Java & 4,99 & 4,63 & 4,57 & 4,51 \\
\hline Yogyakarta & 4,07 & 2,72 & 3,02 & 3,35 \\
\hline East Java & 4,47 & 4,21 & 4,00 & 3,99 \\
\hline
\end{tabular}

Source: Central Bureau of Statistics DIY, 2019

Table 1 shows in 2015 the unemployment rate of D.I Yogyakarta was at 4,07 percent decreased to 2,72 percent in 2016. However, the unemployment rate in 2017 at 3,02 percent compared in 2016 at 2,72 percent. The unemployment rate in 2018 at 3,35percent compared with the unemployment rate in 2017 was 3,02 percent. From the table, we can conclude that the unemployment rate has been increasing from 2017 to 2018. Meanwhile, the open unemployment rate based on the age group from 2015 to 2018 can be seen in the following table:

Table 2.Open Unemployment Rate Based on Age Group in Yogyakarta (\%)

\begin{tabular}{|c|c|c|c|c|}
\hline \multirow{2}{*}{ Group Age } & \multicolumn{4}{|c|}{ Year } \\
\cline { 2 - 5 } & $\mathbf{2 0 1 5}$ & $\mathbf{2 0 1 6}$ & $\mathbf{2 0 1 7}$ & $\mathbf{2 0 1 8}$ \\
\hline $15-19$ & 21,59 & 20,53 & 17,06 & 23,00 \\
\hline $20-24$ & 10,19 & 10,41 & 12,40 & 12,76 \\
\hline $25-29$ & 6,91 & 3,27 & 4,23 & 7,00 \\
\hline $30-34$ & 2,11 & 3,64 & 1,37 & 2,80 \\
\hline $35-39$ & 1,33 & 2,19 & 1,24 & 1,30 \\
\hline $40-44$ & 0,90 & 0,84 & 1,14 & 0,88 \\
\hline $45-49$ & 1,75 & 0,82 & 1,93 & 0,28 \\
\hline $50+$ & 0,98 & 0,23 & 1,02 & 0,17 \\
\hline
\end{tabular}

Source: Central Bureau of Statistics DIY 
Table 2 shows the open unemployment rate dominated by 15-24 years old. The age group between 15-19 is decreased compared in 2016 as much as 20.53 percent but in 2018 has increased by 23.00 percent. The cause of this phenomenon is likely due to the low quality of education in the 15-19 years old age group, making it difficult to find employment opportunities. On the other hand, those who are 20-24 years old may be highly educated but choose to be unemployed because they are waiting for jobs that are more appropriate to their level of education or due to lack of work experience.

Millennial, also known as Generation Y are the demographic cohort following generation $\mathrm{X}$ and preceding generation Z. According to Stafford and Griffis (2008) the range year of birth of Millennials generation is between 1980 to 2000. When the demographic bonus occurs, the millennial generation which is the largest population of productive age plays an important role. For this reason, maximizing the demographic bonus can be done through the potential of the millennial generation. Entering the workforce, millennials will have various professions, but in general, the millennial generation has different characteristics from the previous generations (generation $\mathrm{X}$, baby boom generation, and veteran generation). To maximize the potential of the millennial generation it is necessary to understand the characteristics possessed. Understanding the characteristics of millennials will have its urgency in the demographic bonus times. Moreover, if you look at the condition of Indonesia which has entered the MEA, it means that competition for labor is not only between Indonesian citizens, but also with foreign citizens, then developing competencies, increasing productivity, and educating local labor must be fulfilled.

Millennials have opportunities for innovation. The creation of a digital ecosystem has succeeded in creating a diverse range of business fields that are mushrooming in Indonesia. Evidenced by the proliferation of online companies or businesses, both in the trade and transportation sectors. With this innovation, the millennial generation of Indonesia managed to create a solution to overcome congestion in big cities with online transportation, especially DKI Jakarta. Besides, they managed to have a large economic impact on motorcycle taxi drivers involved in it. While the presence of e-commerce businesses by millennials Indonesia can facilitate millennials that have an entrepreneurial spirit to develop. These examples of innovation prove that the millennials of Indonesia can realize economic independence.

Popescu, (2016) confirmed that the need for achievement and the tendency to take risks make a significant contribution in determining the intention to do entrepreneurship for students in Romania. Ironically, high school graduates with an entrepreneurship field tend to be less interested in engaging in the business world compared to graduates from tertiary institutions offering general education. While, Ifeanyi (2018) to explore that there is a positive relationship between gender, age, career choices, parents' occupation, and entrepreneurial intentions of undergraduate students in Electronic Technology Education. In contrast to Cristian, Constantin, and Sasu (2015)also conducted research related to factors influencing the intensity of entrepreneurship in Romania by using gender variables and family background. The results of his research confirm that men have higher entrepreneurial intentions and assume that monetary rewards are very important. Interesting research on entrepreneurship has been carried out by Fragoso, et al(2019), among students from universities in two countries, namely Brazil and Portugal. The research aims to determine the extent to which the variables of personality, entrepreneurship training and education, social recognition, self-efficacy, and entrepreneurial attitudes affect motivation for entrepreneurship. They also evaluated gender, country of origin, and family background variables. The results of the study revealed that personality traits, selfefficacy, and entrepreneurial attitudes were strong predictors of entrepreneurial motivation while 
social recognition and country of origin gave no significant signal to entrepreneurship motivation for students in both Brazil and Portugal.

Among millennials, several factors that significantly influence the intensity of entrepreneurship are knowledge, experience, and bonds, which are moderated by variables of attitude, norms, behavioral control, and personality traits (Wei-Loon, 2012). The intensity of entrepreneurship is also influenced by several factors including personal attitudes, behavioral control, and perception of support (Sylvia, et.al, 2016).Among academics where working as an entrepreneur is the second choice, variables gender, family business experience, and the type of study program that significantly influences their motivation for entrepreneurship (Sujani, 2011). The intensity of entrepreneurship of African students who are studying in China is strongly influenced by the training in economics and engineering, as well as the need to develop motivation and stimulate entrepreneurial spirit carried out by the government when they return to their home countries (Wang, 2014).

Based on the data and phenomena described, the researcher would like to do a research the entrepreneurial intention of the millennial generation to become an entrepreneur. The reason of researcher chooses millennials is because the amount of unemployed age in Yogyakarta is dominated by millennials even with the bonus demography situation. What distinguishes this research from other research is the presence of perceived behavioral control variables. Perceived behavioral control refers to people's perceptions of their ability to perform a given behavior. Using perceived behavioral control to distinguish the entrepreneurial intention of millennialsis suitable because people's perceptions of their ability for being an entrepreneur will most likely be the factor affecting people's entrepreneurial intentions.

The researcher chooses the age range by Stafford and Griffis's opinion which states that the millennial generation is a population born between 1980 and 2000. Whilst millennial generations have an important role because they usually have brilliant ideas that are creative, innovative, and often unthinkable beforehand. With such great potential, millennial should the best potential to be guided into a brilliant entrepreneur. With the current bonus demography, there will be an opportunity for the millennial generation to be able to provide opportunities to realize their aspirations by making their own business, becoming a smart financial planner, and being able to manage finances independently.

\section{Millennials Generation}

\section{LITERATURE REVIEW}

According to Mannheim (1928)generation is a social construction in which there is a group of people who share the same age and historical experience. Individuals who are part of one generation are those who have the same year born in 20 years and are in the same social dimension and historical dimension. Ryder (1965)defines that generation is an aggregate of groups of individuals who experience the same events in the same period. Theories about generation differences were popularized by Neil Howe and William Strauss in 1991. Strauss and Howe(1991) divided generations based on the similarity of birth times and similarities in historical events. Other sources of 86 states that millennials or Generation $\mathrm{Y}$ are those born between 1980 and 2001. This opinion is similar to Stafford and Griffis (2008)which states that millennials generation is a population born between 1980 and 2000. Whereas the millennial generation according to (Census Bureau Reports, 2015)is those born between 1982 and 2000. 
According to Purwandi (2019) in their book Millennial Nusantara, millennial generations are those born between 1981 and 2000. While other domestic social researchers use birth years from the 1980 s to the 2000 s to determine the millennial generation.

\begin{tabular}{|c|c|c|c|c|c|c|c|c|c|c|c|}
\hline \multirow{2}{*}{ Researchers } & \multicolumn{11}{|c|}{ Year of Birth } \\
\hline & 1976 & 1978 & 1980 & 1981 & 1982 & 1985 & 1990 & 1995 & 1999 & 2000 & 2001 \\
\hline \multicolumn{12}{|l|}{$\begin{array}{l}\text { Tapscott } \\
(1998)\end{array}$} \\
\hline \multicolumn{12}{|l|}{$\begin{array}{l}\text { Martin } \\
\text { \&Tulgan } \\
(2002)\end{array}$} \\
\hline \multicolumn{12}{|l|}{$\begin{array}{l}\text { Zamke et al } \\
(2000)\end{array}$} \\
\hline \multicolumn{12}{|l|}{$\begin{array}{l}\text { Bencsik, } \\
\text { Csikos, Juhez } \\
\text { (2016) }\end{array}$} \\
\hline \multicolumn{12}{|l|}{$\begin{array}{l}\text { Darlene E } \\
\text { Stafford and } \\
\text { H.S Griffis }\end{array}$} \\
\hline \multicolumn{12}{|l|}{$\begin{array}{l}\text { Millennial gen } \\
\text { review NCF }\end{array}$} \\
\hline \multicolumn{12}{|l|}{ SezinBaysal } \\
\hline \multicolumn{12}{|l|}{$\begin{array}{l}\text { Oblinger } \\
(2005) \\
\end{array}$} \\
\hline \multicolumn{12}{|l|}{$\begin{array}{l}\text { Lancaster \& } \\
\text { Stillman } \\
(2002)\end{array}$} \\
\hline \multicolumn{12}{|l|}{$\begin{array}{l}\text { Howe } \\
\& \text { Staruss } \\
(2000) \\
\end{array}$} \\
\hline \multicolumn{12}{|l|}{$\begin{array}{l}\text { PenelitiSosial } \\
\text { (sindonews) }\end{array}$} \\
\hline \multicolumn{12}{|l|}{$\begin{array}{l}\text { US Census } \\
\text { Berau }\end{array}$} \\
\hline $\begin{array}{l}\text { Hasanuddin } \\
\text { Ali and } \\
\text { LilikPurwandi } \\
\text { (2017) } \\
\end{array}$ & & & & & & & & & & & \\
\hline
\end{tabular}

Figure 1. Recap of Millennial Generation by Year of Birth Based on Various Researchers

Figure 1 shows several opinions from experts from various countries and the profession, determining who the millennial generation can be concluded that the millennial generation is those born between 1980 and 2000. Furthermore, the concept of the millennial generation of Indonesia is that the Indonesian population born between 1980-2000 is used as a reference for processing data in the presentation of profiles in later chapters(IDN Research Institute, 2019) 


\section{Entrepreneurial Intention}

Entrepreneurs are people who dare to take risks to open a business on various occasions. Brave soul taking risks means being mentally independent and daring to start a business, without being overwhelmed by fear or anxiety even in uncertain conditions (Kasmir, 2006)

Meredith (2002) states that entrepreneurs are people who can see and assess business opportunities to collect and the resources needed to take advantage of it and take appropriate actions to ensure success. Zimmerer (2002) an entrepreneur is someone who creates a new business by taking risks and uncertainties to achieve profit and growth by identifying opportunities and combining the resources needed to establish them. The assumption is that businesses that want to learn continuously will contribute positively to the implementation. Wulandari (2000)defining entrepreneurial interest as a psychological phenomenon to focus attention and do something about the entrepreneur with a feeling of pleasure because it brings benefits to him. According to Mustofa (2014), interest in entrepreneurship is a focus on entrepreneurship because of the feeling of liking and accompanied by the desire to learn, know, and prove further towards entrepreneurship.

Ajzen's(1991)intention is the immediate antecedent of behavior. He claimed that behavior is not performed mindlessly but follows reasonably and consistently from the behaviour-relevant information and behavior reinforced by rewarding events and weakened by pushing events. According to Ayob, Yap, Sapuan, \& Rashid (2013) and Islam \& Miajee (2018), intention serves as a mediating factor between entrepreneurial action and potential exogenous influence (traits, demographics, skills, social, cultural, and financial support). They suggested that entrepreneurial intention helps in explaining the reasons why certain individuals tend to start their own business before opportunity scan or deciding type of business to involve in. They stated that entrepreneurs themselves should benefit from a better understanding of their motives; intention affords them a chance to understand what factors drive them to make their decisions to pursue an entrepreneurial career and how the venture becomes reality.

The interest in entrepreneurship arises because of the knowledge and information about entrepreneurship which then continues to participate directly in the search for experience and finally the desire to pay attention to the experience that has been gained. As well as having a feeling of being happy and having the desire to be involved in risk-taking activities, to run a business or own business by utilizing existing business opportunities, and creating new businesses with innovative approaches. Entrepreneurial interests are not taken for granted, but can be fostered and developed. There are several factors that affect one's desire to choose the path of entrepreneurship as a way of life. These factors are individual factors, work atmosphere, education level, personality (personality), educational achievement, family motivation, environment, and association, wanting to be more respected or self- respecting, as well as compulsion and circumstances Hendro (2008). Meanwhile, Meredith (2002)explains there is several factors influence the intention of entrepreneurship:

\section{Attitude}

Ajzen and Fishbein (2005)say attitude is a disposition to respond positively or negatively to a behavior. Attitudes toward behavior are determined by belief about the consequences of a behavior, which is called behavioral beliefs. Attitudes toward behavior are defined as the degree of a positive or negative assessment of individuals towards certain behaviors. Attitudes toward behavior are determined by a combination of behavioral belief and outcome evaluation. Behavioral belief is an individual's belief about the positive or negative consequences of a 
particular behavior and the outcome evaluation is an individual evaluation of the consequences he will get from a behavior.

\section{Perceived Behavioural Control}

Ajzen and Fishbein (2005) describe perceived behavioral control as a function based on a belief called control beliefs, namely individual beliefs about the presence or absence of factors that support or hinder an individual from giving rise to behavior. Belief is based on the individual's previous experience of behavior, information that an individual has about a behavior that is obtained by making observations on knowledge possessed by themselves and other people known to individuals, and also by various other factors that can increase or decrease individual feelings about levels difficulty in carrying out a behavior.

\section{Family Background}

Family is the first social group in human life where he learns and declares himself as a social human in the interaction relationship with his group. In association, which involves sympathetic social interaction, a child first learns to pay attention to the wishes of others, learns to work together, helps to help, in other words, children first learn to play a role that involves the social who has norms and skills certain in association with other people (Sobur, 2009)

\section{Social Media}

According to Hermawan (2009), social media is a medium of change about the way people find, read, and distribute news, information, and content to others. Social media is also a combination of sociology and technology that transforms a monologue (one to many) into dialogue (many to many) and information democracy that turns people from content readers into content publishers.

\section{Entrepreneurship Knowledge}

According to (Ropke, 2004)stated that entrepreneurship is the process of creating something new (new creation) and making something different from what is already there (innovation), the goal is the achievement of individual welfare and added value to society. Entrepreneurship is a creative and innovative ability that is used as a basis, tips, and resources to find opportunities for success.

\section{Previous Studies}

Research on entrepreneurship has been widely carried out by researchers in the world. Umukoro and Okurame (2018)researched age differences in the predictive role of entrepreneurial mentoring on career adaptation and tolerance for ambiguity among potential entrepreneurs in Nigeria. The results of the study indicate that the effect of entrepreneurial guidance on career adaptability has a significant impact on relatively younger entrepreneur and the effect is stronger among the first than the last. However, age alone does not moderate the influence of mentoring on tolerance for ambiguity. This research supports the adoption of an adaptive guidance model that meets contextual factors (such as age differences) in entrepreneurship education that aims to improve specific modules of career adaptability and other important entrepreneurial traits.

Popescu (2016) conducted a study related to motivation to do entrepreneurial business in a student environment in several universities in Romania by using variables including: creativity, locus of control, the need for achievement, and the tendency to take risks. The results of empirical studies conclude that the need for achievement and the tendency to take risks make a 
significant contribution in determining the intention to do entrepreneurship for students in Romania. Ironically, high school graduates with an entrepreneurship field tend to be less interested in engaging in the business world compared to graduates from tertiary institutions offering general education. Research on entrepreneurship for students was also carried out by Ohanu (2018)to explore whether the determinants of entrepreneurship motivation for students in universities that offer electronics technology education. The results of the study confirm that there is a positive relationship between gender, age, career choices, parents' occupation, and entrepreneurial intentions of undergraduate students in Electronic Technology Education.

In contrast to Cristian, Constantin, and Sasu (2015)also conducted research related to factors influencing the intensity of entrepreneurship in Romania by using gender variables and family background. The results of his research confirm that men have higher entrepreneurial intentions and assume that monetary rewards are very important. Meanwhile, from the point of view of women, what is more, important is the meaning of their lives. Constantin's study also shows that family background gives a positive and significant contribution to entrepreneurship intentions. Interesting research on entrepreneurship has been carried out by Fragoso, et al(2019) among students from universities in two countries, namely Brazil and Portugal. The research aims to determine the extent to which the variables of personality, entrepreneurship training and education, social recognition, self-efficacy, and entrepreneurial attitudes affect motivation for entrepreneurship. They also evaluated gender, country of origin, and family background variables. The results of the study revealed that personality traits, self-efficacy, and entrepreneurial attitudes were strong predictors of entrepreneurial motivation while social recognition and country of origin gave no significant signal to entrepreneurship motivation for students in both Brazil and Portugal.

Maftuah and Suratman (2015) also researched the influence of Self-Efficacy, Family Environment and Entrepreneurship Knowledge on entrepreneurial intention among students in Sidoarjo. The result of the study confirmed that all of the variables have a positive and significant impact on the entrepreneurial intention of students in Sidoarjo. Similar research was also conducted by Ni et al., (2012). The study aims to examine the effect of several research variables, namely: attitude towards behavior, subjective norm, perceived behavioral control, entrepreneurship education, and personality traits on entrepreneurial intention among students of a higher learning institutions. The findings of this study are all variables that have a significant relationship to entrepreneurial intention.

A study related to entrepreneurial motivation was also conducted by Indarti (2015). The study was conducted to determine what factors affecting entrepreneurial intention among Indonesian students. The factors used in this study are self-efficacy, need for achievement, locus of control, and instrumental readiness. The result of the study shows that self-efficiency and instrumental readiness have a positive and significant effect on entrepreneurial intention. It was further explained, need for achievement and locus of control did not have a positive and significant effect on entrepreneurial intention students in Indonesia. Another research conducted by Wang and Lin (2016)about determinants of internet entrepreneurship intentions among business school students. The variables used in this study are relative advantage, complexity, compatibility, subjective norm, and perceived behavioral control. The findings of their study that compatibility, subjective norm, and perceived behavioral control have positively significant to internet entrepreneurship. Meanwhile, relative advantage and complexity do not affect significantly the intention of internet entrepreneurship. Most business school students are still in the stage of establishing their career choice preferences. 
Interesting research among millennials was conducted by Wei-Loon (2012). The research which taking Thailand as the case study, explored several factors that significantly influence the intensity of entrepreneurship are knowledge, experience, and bonds, which are moderated by variables of attitude, norms, behavioral control, and personality traits. The intensity of entrepreneurship is also influenced by several factors including personal attitudes, behavioral control, and perception of support (Sylvia, et.al, 2016). Among academics where working as an entrepreneur is the second choice, while variables gender, family business experience, and the type of study program that significantly influences their motivation for entrepreneurship (Sujani,2011).Many students from Africa who have been studying at several universities in China motivated Wang (2014) to conduct research related to what factors would have got an impact on the intensity of their entrepreneurship. The results showed that the intensity of entrepreneurship of African students who are studying in China is strongly influenced by the training in economics and engineering, as well as the need to develop motivation and stimulate entrepreneurial spirit carried out by the government when they return to their home countries (Wang, 2014).

Listyawati (2017) conducted a study about the influence of attitude, subjective norm, and control of assessment on the number of businesses students in Yogyakarta. This study aims to examine whether attitudes towards behavior, subjective norm, and perceived behavioral control have a positive and significant effect on entrepreneurial motivation. The test results indicate that there is a significant influence of attitude, subjective norms, and perceived behavioral control variables on student entrepreneurial intentions. The existence of this influence shows that all variables are predictors of a student's entrepreneurial intentions. Ferreeira et al.(2012) were also conducted a study on entrepreneurial intention. The variables used in this study were attitudes towards behavior, subjective norm, and perceived behavioral control. Results show that the need for achievement, self-confidence, and personal attitude affect entrepreneurial intention. Furthermore, subjective norms and personal attitudes affect perceived behavioral control.

\section{DATA AND DATA COLLECTION}

The data that will be obtained for this research and will be analyzed using quantitative research. The object of the research is the millennial generation in Yogyakarta. The subject used in this research is people with the year of birth from 1980 to 2000 or people aged between 19 to 39 years old (Stafford and Griffis, 2008). The data used in this study are primary. The purposive sampling method is a sampling technique that considers several requirements for the source of data taken. The number of people aged 19 to 39 from each sub-district in Kota Yogyakarta amounts to 129.455 people(Bureau Regional Secretariat Administration Yogyakarta, 2018). The sample of this study is 100 samples. A questionnaire is a data collection tool in the non-test assessment, in the form of a series submitted to respondents.

Likert scale is the scale used to measure the response of the subject in the form of attitudes, opinions, and perceptions of a person or group of events or social phenomena to within 5 points of scale at the same interval (Erlina, 2011). The scale works by confronting a respondent with a question and then being asked to answer the questions that have been given. The response is collected and the answer indicates by giving the number 4 for the highest and the score 1 for the lowest or vice versa. 


\section{VARIABLE OPERATIONALIZATION}

This research uses two variables; there are dependent variables and independent variables. The dependent variable is Entrepreneurial intention, and the independent variable is Attitude, Perceived Behavioural Control, Family Background, and Social Media. These data were operationalized as the table below:

Table 3.Variable Operationalization

\begin{tabular}{|c|c|c|c|}
\hline Variable & Definition & Indicator & $\begin{array}{c}\text { Measurement } \\
\text { Scale }\end{array}$ \\
\hline Attitude (X1) & $\begin{array}{l}\text { Attitude is a disposition to } \\
\text { respond positively or } \\
\text { negatively to a behavior. } \\
\text { Attitudes toward behavior } \\
\text { are determined by belief } \\
\text { about the consequences of a } \\
\text { behavior, which is called } \\
\text { behavioral beliefs }\end{array}$ & $\begin{array}{l}\text { 1. The assumption of } \\
\text { entrepreneurs is a challenging } \\
\text { job } \\
\text { 2. Want to be a leader/ boss in } \\
\text { our own company } \\
\text { 3. Freedom to make decisions in } \\
\text { entrepreneurship } \\
\text { 4. Make a new business } \\
\text { 5. Enthusiastic in the business } \\
\text { world }\end{array}$ & Likert \\
\hline $\begin{array}{c}\text { Perceived } \\
\text { Behavioral } \\
\text { Control (X2) }\end{array}$ & $\begin{array}{l}\text { Perceived behaviorl is a } \\
\text { function based on a belief } \\
\text { called control beliefs, } \\
\text { namely individual beliefs } \\
\text { about the presence or } \\
\text { absence of factors that } \\
\text { support or hinder an } \\
\text { individual from giving rise } \\
\text { to a behavior }\end{array}$ & $\begin{array}{l}\text { 1. Confidence in managing a } \\
\text { business } \\
\text { 2. Human resource leadership } \\
\text { 3. Mental maturity in starting a } \\
\text { business } \\
\text { 4. Having firm confidence in } \\
\text { starting a business } \\
\text { 5. The ability to start a business }\end{array}$ & Likert \\
\hline $\begin{array}{l}\text { Family } \\
\text { Background } \\
\text { (X3) }\end{array}$ & $\begin{array}{l}\text { Family is the first social } \\
\text { group in human life where } \\
\text { he learns and declares } \\
\text { himself as a social human } \\
\text { in the interaction } \\
\text { relationship with his group }\end{array}$ & $\begin{array}{l}\text { 1. The way parents educate } \\
\text { 2. Family economic situation } \\
\text { 3. Parental support } \\
\text { 4. Attention of parents }\end{array}$ & Likert \\
\hline $\begin{array}{l}\text { Entrepreneurs } \\
\text { hip } \\
\text { Knowledge } \\
\text { (X4) }\end{array}$ & $\begin{array}{l}\text { Entrepreneurship is a tool } \\
\text { from the viewpoint of } \\
\text { someone who wants } \\
\text { freedom in the economy to } \\
\text { create something new by } \\
\text { using existing resources }\end{array}$ & $\begin{array}{l}\text { 1. Field of Study } \\
\text { 2. Experience in } \\
\text { Entrepreneurship } \\
\text { 3. Roles and responsibilities in } \\
\text { handling a business } \\
\text { 4. Courage to take risks } \\
\text { 5. Management of human } \\
\text { resources } \\
\text { 6. Marketing Management }\end{array}$ & Likert \\
\hline
\end{tabular}




\begin{tabular}{|c|c|c|c|}
\hline $\begin{array}{l}\text { Social Media } \\
\text { (X5) }\end{array}$ & $\begin{array}{l}\text { Social media is a medium } \\
\text { of change about the way } \\
\text { people find, read ,and } \\
\text { distribute news, } \\
\text { information, and content to } \\
\text { others. Social media is also } \\
\text { a combination of sociology } \\
\text { and technology that } \\
\text { transforms a monologue } \\
\text { (one to many) into dialogue } \\
\text { (many to many) and } \\
\text { information democracy that } \\
\text { turns people from content } \\
\text { readers into content } \\
\text { publishers }\end{array}$ & $\begin{array}{l}\text { 1. Communicate } \\
\text { through social media } \\
\text { 2. Join the } \\
\text { entrepreneurship } \\
\text { community on social } \\
\text { media } \\
\text { 3. Planning to } \\
\text { introduce business } \\
\text { through the social } \\
\text { media community } \\
\text { 4. Access fees } \\
\text { 5. Ease of measuring } \\
\text { promotional reach } \\
\text { 6. As an } \\
\text { entrepreneurial media } \\
\text { 7. Updating the latest } \\
\text { news about } \\
\text { entrepreneurship } \\
\text { 8. The ease of } \\
\text { determining the target } \\
\text { market }\end{array}$ & Likert \\
\hline $\begin{array}{l}\text { Entrepreneuri } \\
\text { al Intention } \\
\text { (Y) }\end{array}$ & $\begin{array}{l}\text { Entrepreneurial interest is a } \\
\text { psychological phenomenon } \\
\text { to focus attention on and do } \\
\text { something about the } \\
\text { entrepreneur with a feeling } \\
\text { of pleasure because it } \\
\text { brings benefits to him. }\end{array}$ & $\begin{array}{l}\text { 1. Planning to start a } \\
\text { business } \\
\text { 2. Improve social } \\
\text { status and self-esteem } \\
\text { as an entrepreneur } \\
\text { 3. Choosing } \\
\text { entrepreneurship } \\
\text { rather than working } \\
\text { for others } \\
\text { 4. Get better income }\end{array}$ & Likert \\
\hline
\end{tabular}

\section{RESEARCH FINDINGS AND DISCUSSION}

\section{Multiple Linear Regression Analysis}

Table 4.Summary of Multiple Linear Regression analysis

\begin{tabular}{|c|c|c|c|c|c|c|}
\hline \multicolumn{2}{|c|}{ Model } & \multicolumn{2}{|c|}{$\begin{array}{c}\text { Unstandardized } \\
\text { Coefficients }\end{array}$} & $\begin{array}{c}\text { Standardized } \\
\text { Coefficients }\end{array}$ & \multirow{2}{*}{ t } & \multirow{2}{*}{ Sig. } \\
\cline { 3 - 7 } & B & $\begin{array}{c}\text { Std. } \\
\text { Error }\end{array}$ & Beta & & \\
\hline 1 & (Constant) & 1.814 & .937 & & 1.935 & .056 \\
\hline
\end{tabular}




\begin{tabular}{|l|l|c|c|c|c|}
\hline Attitude & .184 & .091 & .190 & 2.018 & .046 \\
\hline $\begin{array}{l}\text { Perceived } \\
\text { Behavioral } \\
\text { Control }\end{array}$ & .250 & .085 & .298 & 2.935 & .004 \\
\hline $\begin{array}{l}\text { Family } \\
\text { Background }\end{array}$ & .137 & .068 & .154 & 2.007 & .048 \\
\hline $\begin{array}{l}\text { Entrepreneurship } \\
\text { Knowledge }\end{array}$ & .129 & .090 & .136 & 1.437 & .154 \\
\hline Social Media & .111 & .055 & .188 & 2.004 & .048 \\
\hline
\end{tabular}

Source: Appendix G

Table 5 shows the Standardized Coefficients section Beta obtained the value of attitude is 0.190 , perceived behavioral control is 0.298, family background is 0.154 , entrepreneurship knowledge is 0.136 and social media is 0.188 . The equation of multiple linear regression analysis in this study is:

$$
Y=0.190 X_{1}+0.298 X_{2}+0.154 X_{3}+0.136 X_{4}+0.188 X_{5}
$$

Based on these equations the variables are interpreted from the multiple regression equation as follows:

The coefficient value of attitude (X1) is 0.190 which means attitude (X1) has a positive impact on entrepreneurial intention or in other words if the attitude of a person is better or if someone's response to entrepreneurship is positive or they have the better or appropriate attitude to become an entrepreneur, their intention of opening a business will be even greater. Their attitude will be so much better if they are surrounded by the entrepreneurship community or join a Bazar to gain more experience.

The coefficient value of perceived behavioral control (X2) is 0.298 which means perceived behavioral control (X2) has a positive impact on entrepreneurial intention or in other words if someone believes he could and capable to be an entrepreneur or start a business, his intention of becoming an entrepreneur is getting bigger which means is more likely he's confident enough to run his own business.

The coefficient value of family background (X3) is 0.154 which means family background (X3) has a positive impact on entrepreneurial intention or in other words if a person was born from an entrepreneur family, they are likely to follow their parent's job or being an entrepreneur as well because they watch their parents experience being an entrepreneur.

The coefficient value of entrepreneurship knowledge (X4) is 0.136 which means entrepreneurship knowledge (X4) has a positive impact on entrepreneurial intention or in other words someone will be more confident to become an entrepreneur if they have entrepreneurship knowledge.

The coefficient value of social media (X5) is 0.231 which means social media (X5) has a positive impact on entrepreneurial intention or in other words if the business field in social media is growing rapidly could attract someone's intention to start a business. Facebook and Instagram 
are examples of social media that provide a business field for people because they don't have to have a big amount of capital to rent a building or a place for starting a new business. They could simply make a business account and they could run sell and buy through social media.

\section{Discussion}

In this study, four hypotheses have been partially tested using multiple linear regression methods. The aim is to find out whether attitude, perceived behavioral control, family background and social media partially influence entrepreneurial intention. The results of partial testing of each independent variable on the dependent variable can be described as follows:

\section{A. Attitude has a positive and significant effect on entrepreneurial intention}

The results showed that attitude has a positive and significant impact on entrepreneurial intention. This is evidenced by the value of $t$ count $<t$ table $(2.018>1.661)$ with a significant level of $0.046<0.05$ (Appendix $G$ ). Thus, the hypothesis which states that attitude has a positive and significant effect on entrepreneurial intention is accepted.

The result of this study is that there is a positive and significant relationship between attitude and entrepreneurial intention. Ajzen and Fishbein (2005) suggest that a person's attitude towards certain objects or behaviors can influence the intention of the person to perform certain behaviors. Attitudes are determined by a combination of individual beliefs about the positive or negative consequences of certain behaviors and individual evaluations of the consequences he will get from a behavior. Most the respondents prefer to become an entrepreneur because they want to make a new type of business. When they open their own business, they will open a new opportunity for unemployed people. According to respondents' responses, most of them are likely to give a positive response about entrepreneurship. Most of them are agree to become an entrepreneur because they understand the rewards that they will get from it. When someone has a positive or negative response to certain things it will determine their intention to act. Attitudes behave to have an important role in the level of intention entrepreneurship. Attitude is a person's view of something. The attitude of behavior also comes from a person's feelings in seeing things, whether they are considered positive or negative that affects a person's attitude towards it.

This result is also supported by another research conducted by Ardiyani and Kusuma (2016) who researched the effects of Attitudes, Education, and Family Environment Against the Interest of Entrepreneurship. Their research indicates that Attitude, entrepreneurship knowledge, and family background have a positive and significant relationship to entrepreneurial intention. Another research was conducted by Listyawati (2017)who researched the influence of attitude, subjective norm, and control of assessment on the number of businesses in Yogyakarta students. Her research indicates that there is a significant effect of attitude variables, subjective norms, and behavioral controls on students' intentions of entrepreneurship.

\section{B. Perceived behavioral control has a positive and significant effect on entrepreneurial intention}

The results showed that perceived behavioral control has a positive and significant impact on entrepreneurial intention. This is evidenced by the value of $t$ count $<\mathrm{t}$ table $(2.935>1.661)$ with a significant level of $0.004<0.05$ (Appendix G). Thus, the hypothesis which states that perceived behavioral control has a positive and significant impact on entrepreneurial intention is accepted.

The result of this study is that there is a positive and significant relationship between perceived behavioral control and entrepreneurial intention. Perceived behavioral control is 
determined by a combination of belief control and perceived power control. Control belief is an individual belief about supporting or inhibiting factors to bring up a behavior. Perceived power control is the strength of individual feelings about each of the supporting or inhibiting factors. According to respondents' responses, most of them feel they have the ability to become an entrepreneur who means they feel that they are confident and capable to start a business perhaps because they are surrounded by people that interested in business so it will affect their personal belief and intention to become an entrepreneur.

The results of this study are also supported by research conducted by Wang and Lin (2016)researched about Determinants of Internet Entrepreneurship Intentions among Business School Students. Their research indicates that compatibility, subjective norm, and perceived behavioral control have a positive and significant impact on entrepreneurial intention.

\section{Family background has a positive and significant effect on entrepreneurial intention}

The results showed that family background has a positive and significant impact on entrepreneurial intention. This is evidenced by the value of $t$ count $<\mathrm{t}$ table $(2.007>1.661)$ with a significant level of $0.048<0.05$ (Appendix G). Thus, the hypothesis which states that family background has a positive and significant impact on entrepreneurial intention is accepted.

The result of this study is that there is a positive and significant relationship between family background and entrepreneurial intention. The family environment is very important in growing interest and encouraging someone to make career decisions as an entrepreneur. Family encouragement can be in the form of attention from parents. Parents who give maximum encouragement to their children can be sure to bring success to their children, whereas if the encouragement given by parents to their children is low, the success rate is also low. Based on respondents' responses, most of the respondent's parents are supporting their children to become an entrepreneur. With support comes from parents, it could impact their child to act. Especially, if someone was born from an entrepreneur family, they are likely to follow their family path. Sometimes their parent's business will eventually down to the hands of his child to continue their family business.

Another similar research that has the same result was research conducted by Santosa (2014)who researched Factors that Influence the Interest of Entrepreneurship STIMIK student Surakarta Nation Ambassadors. His research indicates that family background, entrepreneurship knowledge, profit expectation, and freedom at work have a positive and significant impact on entrepreneurial intention.

\section{Entrepreneurship knowledge and not significant effect on entrepreneurial intention}

The results showed that social media has a positive and significant impact on entrepreneurial intention. This is evidenced by the value of $t$ count $<t$ table (1.437> 1.661) with a significant level of $0.154<0.05$ (Appendix G). Thus, the hypothesis which states that entrepreneurship knowledge has a negative and not significant impact on entrepreneurial intention is rejected.

Entrepreneurship knowledge is everything that someone knows about entrepreneurship. Everyone must have a mind, but only a few have ideas, so knowledge is needed in entrepreneurship so that creative and innovative ideas or ideas can bring forth forms of entrepreneurship that continue to be actual and have trends in consumer needs. The assumption is that businesses that want to learn continuously will contribute positively to the implementation of innovative management. 
Another similar research was conducted by (Nurhalimah, 2017) about the Effect of Entrepreneurship Knowledge, Family Factors, and Personality Factors Against Interest in Entrepreneurship at Student Management Concentration Entrepreneurship S-I Faculty Management in University and Business Economics of North Sumatra. The result of her study entrepreneurship knowledge and family factors donot impact entrepreneurial intention where personality factors do impact entrepreneurial intention.

\section{E. Social media has a positive and significant effect on entrepreneurial intention}

The results showed that social media has a positive and significant impact on entrepreneurial intention. This is evidenced by the value of $t$ count $<t$ table $(2.004>1.661)$ with a significant level of $0.048<0.05$ (Appendix G). Thus, the hypothesis which states that family background has a positive and significant impact on entrepreneurial intention is accepted.

The result of this study is that there is a positive and significant relationship between social media and entrepreneurial intention. The advantages possessed by social media such as easy communication and do not spend a lot of time in communication, supported by efficiency where the majority of respondents agree that social media can be accessed anywhere and do not require a lot of costs, making social media an appropriate alternative for students who mostly do not have income itself to try entrepreneurship. Based on the respondent's responses result, most of them are strongly agree that using social media to open a business does not cost a lot of money. Usually, when someone wants to open a business, they need to rent or buy a building. Social media nowadays, for example Instagram is providing a page to open a business account thus if we would like to open a business using one of the social media platforms it could reduce the cost of renting a building. Another similar research was conducted by Fatmawati (2018)who researched the influence of self-efficacy, family environment, and Social media on interest in becoming entrepreneurs in the students of Business Administration Study Program, University of Sumatra Utara. He indicates that self-efficiency, family background, and social media have a positive and significant impact on entrepreneurial intention.

\section{CONCLUSION}

Based on the results of the analysis and discussion presented in the previous chapter, conclusions can be taken as follows:

1. Based on the results of the F-Test, it was explained that the attitude, perceived behavioral intention, family background, entrepreneurship knowledge, and social media have a positive and significant effect on the entrepreneurial intention of the millennial generation in Yogyakarta.

2. Based on the results of the T-Test, it was explained that the attitude, perceived behavioral intention, family background, and social media have a positive and significant impact on entrepreneurial intention while entrepreneurship knowledge has a negative and not significant effect on entrepreneurial intention.

3. The results of testing the coefficient of determination (R2) obtained the value of Adjusted R Square shows the amount of R20.695 or $69.5 \%$. Therefore, the magnitude of the influence of attitude, perceived behavioral intention, family background, and social media on entrepreneurial intention as much as $69.5 \%$. The rest is equal to $30.5 \%$ is influenced by other factors not examined in this study. 


\section{REFERENCES}

Ajzen, I. (1991). The Theory of Planned Behavior, Organizational Behavior and Human Decision Processes, 50(2).

Ayob, N., Yap, C. S., Sapuan, D. A., \& Rashid, M. Z. A. (2013). Social entrepreneurial intention among business undergraduates: An emerging economy perspective. Gadjah Mada International Journal of Business, 15(3), 249-267.

Ajzen, I. \& Fishbein, M. (2005). The influence of attitudes on behavior, The handbook of attitudes, 173(221), 31.

Ardiyani, N. \& Kusuma, A. (2016). The effects of Attitude, Education and Family Environment on Interest in Entrepreneurship, E-Jurnal Manajemen Universitas Udayana, 5(8), 51555183.

Bureau Regional Secretariat Administration Yogyakarta. (2018). The amount of Population Yogyakarta in 2018.

Berkup, S. B. (2014). Working with generations X and Y in generation Z period: Management of different generations in business life. Mediterranean Journal of Social Sciences, 5(19), 218-218.

Census Bureau Reports. (2015). Millennials Outnumber Baby Boomers and Are Far More Diverse.

Constantin \& Sasu, L. (2015). Demographic Determinant of the Entrepreneurship Intentions. The Case of Romania', Procedia Economics and Finance, 20, 580-585.

Erlina. (2011). Research Methodology: Accountant. Medan: USU PRESS.

Fatmawati, R. (2018). The Influence Of Self-Efficacy, Family Environment And Social Media On Interest In Becoming Entrepreneurs In The Students Of Business Administration Study Program, University of Sumatera Utara. Universitas Sumatera Utara.

Ferreira, J. J., Raposo, M. L., Rodrigues, R. G., Dinis, A., \& Paço, A. D. (2012). A model of entrepreneurial intention: An application of the psychological and behavioral approaches. Journal of Small Business and Enterprise Development, 19(3), 424-440.

Fragoso, R., Rocha-Junior, W., \& Xavier, A. (2019). Determinant factors of entrepreneurial intention among university students in Brazil and Portugal, Journal of Small Business \& Entrepreneurship, 31.

Hendro, I. (2008). Basic of Entrepreneurship. Erlangga.

Hermawan, C. W. (2009). Adobe Dreamweaver CS4. Yogyakarta: ANDI. 
IDN Research Institute. (2019). Indonesia Millennial Report 2019, IDN Media.

Indarti, N. (2015). Factors Affecting Entrepreneurial Intentions Among Indonesian Students', Journal of Indonesian Economy and Business, 19(1), 57-70.

Islam, K. A., \& Miajee, M. R. K. (2018). Small and Medium Enterprises (SMEs) Financing in Bangladesh: A Review of Literature. International Journal of Small and Medium Enterprises, 1(1), 11-15. https://doi.org/10.46281/ijsmes.v1i1.62

Kasmir. (2006). Entrepreneurship. Jakarta : RajaGrafindo Persada.

Listyawati, I. H. (2017). The effect of Attitude, Norms Subjective and Perceived Behavioral Control on Entrepreneurial Intention in Yogyakarta', Jbma, 4(1), 57-68.

Lee, W. N., Lim, B. P., Lim, L. Y., Ng, H. S., \& Wong, J. L. (2012). Entrepreneurial Intention: a Study Among Students of Higher Learning Institution, Entrepreneurial Intention: a Study Among Students of Higher Learning Institution, (August), p. 15.

Maftuah, R. \& Suratman, B. (2015). The Influence of Self-Efficacy, Family Environment and Entrepreneurship Knowledge on Student Entrepreneurship Interests in Sidoarjo, Jurnal Ekonomi Pendidikan dan Kewirausahaan, 3(1),121-131. Retrieved from https://journal.unesa.ac.id/index.php/jepk/article/view/749.

Mannheim, K. (1928). Karl Mannheim , Das Problem der Generationen , 1928.

Meredith, G. G. (2002). Kewiraushaan.

Mustofa, M. A. (2014). The Effects Of The Entrepreneurship Knowledge, Self- Efficacy, And Entrepreneurial Character On The Entrepreneurial Interest Grade Xi Students Of Smk Negeri 1 Depok Sleman Regency Kabupaten Sleman. Universitas Negeri Yogyakarta.

Nurhalimah, (2017). Effect of Entrepreneurship Knowledge, Family Factors and Personality Factors Against Interest in Entrepreneurship At Student Management Concentration Entrepreneurship S-I Faculty Management University and Business Economics North Sumatra'.

Ohanu, I. B. (2018). Determinant factors of entrepreneurship intentions of electronic technology education students in Nigerian Universities, Journal of Global Entrepreneurship Research, 8, 36.

Popescu, C. C. (2016). An Analysis of the Determinants of Entrepreneurial Intentions among Students: A Romanian', International Journal Of Sustainability, 8, 771.

Purwandi, L. (2019). Indonesia 2020 : The Urban Middle-Class Millenials INDONESIA 2020 : The Urban Middle-Class Millennials, Alvara Research Center, (April 2016). 
Ropke, J. (2004). On Creating Entrepreneurial Energy Un The Ekonomi Rakyat The Case Of Indonesian Cooperatives, Jurnal Ekonomi KWU, 111, 43-61.

Ryder, N. B. (1965). The cohort as a concept of social change, American Sociological Review, 30(6), 843-861.

Santosa, T. D. (2014). Factors that affect entrepreneurial intentions among students in STMIK Duta Bangsa Surakarta, 7(September), 78-91.

Sobur, A. (2009). Psychology in General. Bandung: Cv. Pustaka Setia.

Stafford, D., \& Griffis, H. (2008). A review of millennial generation characteristics and military workforce implications, Center for Naval Analysis, (May). Retrieved from http://citeseerx.ist.psu.edu/viewdoc/download?doi=10.1.1.148.7496\&rep=rep1\&type=pdf

Strauss, W., \& Howe, N. (1991). Generation.

Umukoro, O. S. \& Okurame, D. E. (2018). Role of mentoring in career adaptability and ambiguity tolerance of potential Nigerian entrepreneurs: the moderating effect of age', Journal of Global Entrepreneurship Research, 8, 33.

Wang, Y. M., \& Lin, Y. S. (2016). Determinants of Internet Entrepreneurship Intentions among Business School Students, International Journal of Information and Education Technology, 6(10), 754-758.

Wulandari, S. (2000). The effects of Self-Efficiency on Entrepreneurial Intention among Students in SMK Negeri 1 Surabaya, Artikel Skripsi, 1-2.

Zimmerer, T. W. (2002). Introduction Entrepreneurship and Management Small Business. 1st eds.

\section{Copyrights}

Copyright for this article is retained by the author(s), with first publication rights granted to the journal. This is an open-access article distributed under the terms and conditions of the Creative Commons Attribution license (http://creativecommons.org/licenses/by/4.0/) 